Arq. Bras. Med. Vet. Zootec., v.71, n.2, p.489-499, 2019

\title{
Addition of chlorogenic acid and caffeine during the processing of cooled boar semen
}

[Adição de ácido clorogênico e cafeína durante o processamento do sêmen suíno resfriado]
B.A. Pereira1
https://orcid.org/0000-0002-3614-7886 L.G.P. Rocha1 $0000-0002-9082-7372$ M.C. Teles C. W.E. Silval
d.org/0000-0002-5441-2620 .A. Barbosa1
ps://orcid.org/0000-0001-8983-3890 S.S. Rabelo
ttps://orcid.org/0000-0002-0000-028 A.S. Uchoa1

B.A. Pereira ${ }^{1}$, L.G.P. Rocha ${ }^{1}$, M.C. Teles ${ }^{1}$, W.E. Silva ${ }^{1}$, J.A. Barbosa ${ }^{1}$, S.S. Rabelo ${ }^{1}$, A.S. Uchoa ${ }^{1}$, J. E. Rodrlguez-Gil ${ }^{2}$, L.J. Pereira ${ }^{1}$, M.G. Zangeronimo ${ }^{1 *}$

${ }^{1}$ Universidade Federal de Lavras - Lavras, MG

${ }^{2}$ Universitat Autónoma de Barcelona, Bellaterra (Cerdanyola del Valles) - Espanha

\section{ABSTRACT}

A study was conducted to evaluate the effect of chlorogenic acid (ChA) added pre-cooling and its combination with caffeine added during warming on cooled-stored boar semen parameters. Ten ejaculates were diluted in commercial extender with or without $4.5 \mathrm{mg} / \mathrm{ml} \mathrm{ChA}$ and stored at $15^{\circ} \mathrm{C}$. After 0,24 and 72 hours of storage, aliquots of these doses were taken and incubated at $37^{\circ} \mathrm{C}$ in the presence or absence of $8.0 \mathrm{mM}$ caffeine. Semen quality was evaluated after 10 and 120 minutes of incubation. The ChA increased $(\mathrm{P}<0.01)$ the sperm motility, viability, acrosomal integrity and the percentage of spermatozoa with high mitochondrial activity (PMHA), however, decreased $(\mathrm{P}<0.01)$ the malondialdehyde (MDA) concentration. Caffeine increased $(\mathrm{P}<0.05)$ the sperm motility, viability, PMHA and the MDA concentration and reduced $(\mathrm{P}<0.05)$ the acrosome integrity. When associated $(\mathrm{ChA}+$ caffeine), there was an increase $(\mathrm{P}<0.05)$ in sperm motility and viability, PMHA and acrosome integrity. The addition of ChA to the dilution medium improves the quality of the swine inseminating doses. The addition of caffeine during re-warming is only recommended when the semen is stored for prolonged periods $(72 \mathrm{~h})$, and the inseminating dose should be used immediately after its addition.

Keywords: antioxidant, boar semen storage, metabolic activator, methylxanthine, polyphenol

\section{RESUMO}

O objetivo deste estudo foi avaliar os efeitos da adição de ácido clorogênico (ChA) antes do resfriamento e sua combinação com cafeína adicionada durante o reaquecimento sobre a qualidade do sêmen suíno resfriado. Dez ejaculados foram diluídos em diluidor comercial com adição ou não de 4,5mg/mL de ChA e armazenados a $15^{\circ} \mathrm{C}$. Após zero, 24 e 72 horas de armazenamento, $10 \mathrm{~mL}$ foram retirados e incubados a $37^{\circ} \mathrm{C}$ na presença ou ausência de $8,0 \mathrm{mM}$ de cafeína. A qualidade seminal foi avaliada após 10 e 120 minutos de incubação. $O$ ChA aumentou $(P<0,01)$ a motilidade, a viabilidade, a integridade acrosomal $e$ a porcentagem de espermatozoides com alta atividade mitocondrial (PMHA), entretanto diminuiu $(P<0,01)$ a concentração de malondialdeído $(M D A)$. A cafeína aumentou $(P<0,05)$ a motilidade, a viabilidade, a PMHA e a concentração de MDA e reduziu a integridade acrossomal. Quando associados $(C h A+$ cafeína $)$, houve aumento $(P<0,05)$ na motilidade, na PMHA, na viabilidade e na integridade acrossomal. Conclui-se que a adição de ChA ao meio de diluição melhora a qualidade das doses inseminantes de suínos. A adição de cafeína durante o reaquecimento só é recomendada ao sêmen adicionado de ChA quando esse for armazenado por períodos prolongados (72h), devendo a dose inseminante ser utilizada imediatamente após sua adição.

Palavras-chave: antioxidante, sêmen suíno armazenado, ativador metabólico, metilxantina, polifenol

Recebido em 6 de dezembro de 2017

Aceito em 15 de maio de 2018

* Autor para correspondência (corresponding author)

E-mail: zangeronimo@dmv.ufla.br 


\section{INTRODUCTION}

Currently, artificial insemination is widely practiced in swine production using fresh seminal doses or stored at $15^{\circ} \mathrm{C}$ for usual periods of 24 to 48 h (Pinart et al., 2013). Although the fertility of boar semen can be maintained under these conditions, cooling for longer periods results in decreased sperm quality. This occurs mainly due to excessive production of reactive oxygen species (ROS) by spermatozoa, which in turn cause oxidative damage in sperm cell membranes compromising viability and sperm function (Waterhouse et al., 2004). The lipid peroxidation of cell membrane induced by ROS alters the structure and function of the sperm, generates DNA damage (Schulte et al., 2010) and reduces intracellular ATP levels and sperm motility (Aitken et al., 2012).

To address these problems, addition of antioxidants in semen extenders have been used, ensuring better quality of the cooled semen (Martin-Hidalgo et al., 2011; Mendez et al., 2013). The chlorogenic acid (ChA) is a polyphenol known for its antioxidant properties in vitro (Rice-Evans et al., 1996) that has been associated with suppressing the activation of transcription factors induced by ROS (Xu et al., 2010). Recently, a study has proved the efficiency of ChA in improving the quality of the cooled boar semen (Pereira et al., 2018). Thus, the addition of antioxidants could have a beneficial effect on increasing the useful storage time of boar semen.

There are other substances that can improve stored boar semen quality. For instance, metabolic activators, such as caffeine, have also been used in this sense. Caffeine is a methylxanthine capable of improving the motility of spermatozoa and mitochondrial activity (Nabavi et al., 2013), resulting in an increase in fertilization rates (Numabe et al., 2001), when added immediately prior of insemination. In swine, there is evidence that the addition of caffeine during the semen rewarming of cooled boar semen reduces the sperm viability, however, increases in the vigour of spermatozoa (Nunes, 2012). The reduction of sperm viability was attributed by the authors to the higher metabolic activity of the cells. In frozen-thawed boar semen, the use of caffeine in the thawing solution improved the progressive motility, straightness, and linearity of sperm movement (Yamaguchi e Funahashi, 2012; Yamaguchi et al., 2013). It is known that caffeine positively affects sperm function by upregulating glycolysis via a buildup of cyclic adenosine monophosphate (cAMP), which generates adenosine triphosphate (ATP), used to power sperm movement (Lardy et al., 1971). Rhemrev et al. (2001) suggested that the motility of the spermatozoa was related to their fertilizing capacity and the sperm motility was dependent on mitochondrial function.

However, one undesirable side effect linked with the utilization of metabolic activators is a concomitant increase of sperm ROS production, which would act against sperm function. Thus, an effective technique to utilize metabolic activators to improve boar semen conservation would include a system that allows us to avoid the undesirable increase in ROS. A possibility would be the simultaneous utilization of a metabolic activator, like caffeine, together with an antioxidant, like ChA. In this manner, the antioxidant effect of the ChA could counteract the caffeine-caused increase in ROS. Taking this into consideration, the main objective of this study was to determine if combined use of ChA, in the dilution media, and caffeine, during rewarming of inseminating doses, could be useful to improve the quality of boar semen stored at $15^{\circ} \mathrm{C}$ until 72 hours.

\section{MATERIALS AND METHODS}

All procedures were approved by the Ethics Committee on Animal Use of UFLA with protocol number 027/13. Ten ejaculates from three fertility proven pure breed boars (Pietrain, Duroc and Large White) were used. The animals were 1.0-1.5 years of age and were kept in individual pens $(3.0 \mathrm{~m}$ long, $2.0 \mathrm{~m}$ wide and $1.30 \mathrm{~m}$ high) received water ad libitum and $3.0 \mathrm{~kg}$ of feed divided into two daily rations. Animals were housed at the Experimental Swine Center; Department of Animal Science, Federal University of Lavras (UFLA; Lavras; Minas Gerais, Brazil).

Ejaculates were obtained using the gloved hand method during routine collection on the farm. After collection, ejaculates were immediately sent to the Laboratory of Swine Breeding (Department of Physiology and Pharmacology, 
UFLA). Initial subjective observations on motility and vigour were carried out on a drop of semen placed between a slide and coverslip previously heated to $37^{\circ} \mathrm{C}$ under phase microscope (Nikon Eclipse E200-LED, Nikon, Tokyo, Japan) at $100 \times$. For analysis of sperm morphology $200 \mu \mathrm{L}$ of fresh semen was addition in $1000 \mu \mathrm{L}$ of formal saline solution, and a drop was evaluated under a phase microscope (Olympus CX31, Olympus Corporation, Hamburg, Germany) at 1000×. Sperm concentration was evaluated in a Neubauer cell counter chamber after dilution of $10 \mu \mathrm{L}$ fresh semen in $1000 \mu \mathrm{L}$ of formal saline solution, and the number of spermatozoa $/ \mathrm{ml}$ was determinate under a phase microscope at (Olympus CX31, Olympus Corporation, Hamburg, Germany) $400 \times$. Only the rich fraction of motile ejaculates was used for processing of insemination doses.

All ejaculates fulfilled the minimum requirements for use in artificial insemination: $>70 \%$ total motility, $<20 \%$ proximal cytoplasmic droplets and total number of spermatozoa $>200 \times 10^{6}$ per $\mathrm{ml}$ (Silva et al., 2011). After the sperm concentration was calculated, the semen volume that contained 1.5 billion sperm was diluted in BTS extender previously prepared and heated to $37^{\circ} \mathrm{C}$ with or without addition of ChA. From each ejaculate, four insemination doses were processed and distributed in a randomized block design (blocked by ejaculate) in a 2 x 2 factorial scheme (with or without ChA, with or without caffeine) in a split plot in time (incubation time of semen) with ten repetitions that were representative of the ejaculate.

For this, immediately before the processing of insemination doses, 180mg of ChA (Chlorogenic acid crystalline, C3878, Sigma-Aldrich Co., Ltd., St. Louis, MO, USA) was diluted in $5.0 \mathrm{ml}$ of BTS extender (Beltsville Thawing Solution ${ }^{\circledR}$, Minitube, Porto Alegre, Brazil) at $37^{\circ} \mathrm{C}$ using an ultrasonic sonicator (QR $300 \mathrm{~W}$, Ultronique, Indaiatuba, Brazil). This solution was then added to the volume of semen that contained 1.5 billion sperm. After, BTS at $37^{\circ} \mathrm{C}$ were then added until the final volume of $40 \mathrm{ml}$, so that each insemination dose contained $4.5 \mathrm{mg}$ of $\mathrm{ChA}$ per $\mathrm{ml}$ of semen (Pereira et al., 2018). Two inseminate doses were processed with $\mathrm{ChA}$ and two without this substance. Then, the $\mathrm{pH}$ of doses was measured using $\mathrm{pH}$-indicator strips (109535, Merck Millipore Corporation,
Darmstadt, Germany). The $\mathrm{pH}$ of all samples remained between 7 and 8 , which is considered ideal for sperm survival (Johnson et al., 2000).

Ninety minutes after this process, all four doses were stored at $15^{\circ} \mathrm{C}$ in a refrigerator. Before storage, a $10 \mathrm{ml}$ aliquot of each insemination dose was heated in test tubes in a water bath at $37^{\circ} \mathrm{C}$. One aliquot from a ChA-added dose and another aliquot from a negative control were supplemented with caffeine $(8.0 \mathrm{mM})$ in a concentration determined in previous study (Nunes, 2012). For this, $15.33 \mathrm{mg}$ of caffeine (pure caffeine, 533, Isofar, Rio de Janeiro, Brazil) was diluted in $1.0 \mathrm{ml}$ of BTS at $37^{\circ} \mathrm{C}$, which was added into $9.0 \mathrm{ml}$ of the inseminate dose. The other two $10 \mathrm{ml}$ aliquots were added to $1.0 \mathrm{ml}$ of BTS without caffeine and they were used as controls for the caffeine effect. After 10 and $120 \mathrm{~min}$ of incubation, all samples were evaluated to determine the percentage of mobile and viable cells, integrity of sperm acrosome, mitochondrial activity of the cells and concentration of glucose to determine the glucose uptake during this time. Furthermore, after $60 \mathrm{~min}$ of incubation samples were collected to determine the concentration of malondialdehyde (MDA). The same incubation procedure was carried out after 24 and $72 \mathrm{~h}$ of storage, with the exception of glucose intake that was evaluated only at 0 and $72 \mathrm{~h}$ of storage.

To evaluate sperm motility, a drop of semen was placed between a slide and a cover slip previously heated to $37^{\circ} \mathrm{C}$. Observations were made using a phase-contrast microscope (Nikon Eclipse E200-LED, Nikon, Tokyo, Japan) with 100x magnification. Two trained persons subjectively evaluated 10 fields, to determine the percentage of motile sperm. Analyses were done blind and in triplicate. The vigour was evaluated using a system scale from 0 to 5 , where 0 represents the absence of movement and 5 is maximum intensity.

Sperm membrane integrity was measured by a smear of drop of semen mixed with a drop of eosin-nigrosin (Blom, 1950). The cells were evaluated under optical microscope (Olympus CX31, Olympus Corporation, Hamburg, Germany) at $400 \times$. The values were expressed by the percentage of cells with intact membranes in relation to the total number of cells counted (200 cells). The same process was used to determine 
the acrosomal integrity, however, a single dye of POPE (Fast Green - F7258 and Rose Bengal 198250, Sigma-Aldrich Co. Ltd., St. Louis, USA) was used (Pope et al., 1991). The mitochondrial oxidative activity was estimated by the DAB technique (Hrudka, 1987) in the same phase contrast microscopy at $1000 \times$ magnification. Only cells with fully stained midpieces that indicate high mitochondrial activity were analyzed. All analyses were performed in duplicate in a blinded manner by the same investigator.

To carry out the biochemical analysis, $1.0 \mathrm{ml}$ semen aliquots were removed at 10, 60 and $120 \mathrm{~min}$ of incubation. Samples were centrifuged in $2.0 \mathrm{~mL}$ centrifuge tubes at $3360 \mathrm{~g}$ for $10 \mathrm{~min}$. Supernatants were then transferred to another centrifuge tube and frozen at $-80^{\circ} \mathrm{C}$ until analysis.

The glucose and malondialdehyde (MDA) concentration in the seminal plasma were measured by enzyme colorimetric methods (Analyze Glucose-PP, Gold Analisa Diagnostica, Belo Horizonte, Brazil and QuantiChromTM TBARS, Assay Kit DTBA-100, Bioassay Systems, Hayward, CA, USA, respectively), following the manufacturer's instructions. The glucose intake by sperm was determined by difference between the glucose concentration in the extracellular medium at 10 and at $120 \mathrm{~min}$ of incubation. The MDA concentration was measured at $60 \mathrm{~min}$ of incutabion.
In relation to statistical analysis, the Shapiro Wilk test was used to evaluate the normality of residuals. Data from motility and sperm viability, and mitochondrial activity were subjected to analysis of variance and means within each main factor (ChA and caffeine) and time of incubation were compared by the $F$ test, considering $\alpha=$ 0.05 . For vigour, a nonparametric statistical analysis was used and the averages were compared using the Friedman test. All statistical analysis was performed with the Action 2.3 statistical program.

\section{RESULTS}

The ChA improved $(\mathrm{P}<0.01)$ the sperm motility after $120 \mathrm{~min}$ of incubation of the semen before and at 24 hours of storage, regardless of the addition of caffeine (Table 1). With 72 hours of storage, ChA improved $(\mathrm{P}<0.01)$ the sperm motility at both 10 and 120 minutes of incubation. Caffeine increased $(\mathrm{P}<0.05)$ the sperm motility only in semen stored for $72 \mathrm{~h}$ at 10min of incubation, both in the presence or absence of ChA. Throughout the incubation for 120 minutes, there was decrease $(\mathrm{P}<0.05)$ of semen motility, with or without addition of caffeine and ChA. Although there was improvement of the motility in some times of evaluation, both caffeine and $\mathrm{ChA}$ failed to maintain sperm motility during $120 \mathrm{~min}$ of incubation.

Table 1. Sperm motility of boar semen containing or not chlorogenic acid $(\mathrm{CH})$ and caffeine $(\mathrm{CA})$, evaluated in different times incubation at $37^{\circ} \mathrm{C}$ after different times of storage at $15^{\circ} \mathrm{C} . \mathrm{n}=10$

\begin{tabular}{|c|c|c|c|c|c|c|c|}
\hline \multirow{2}{*}{$\begin{array}{l}\text { Incubation } \\
\text { time }\end{array}$} & \multirow{2}{*}{$\begin{array}{l}\text { Chlorogenic } \\
\text { acid }\end{array}$} & \multicolumn{2}{|c|}{ Caffeine } & \multirow{2}{*}{ SEM } & \multicolumn{3}{|c|}{$\mathrm{P}=$} \\
\hline & & without & with & & $\mathrm{CA}$ & $\mathrm{CH}$ & $\mathrm{CH} \times \mathrm{CA}$ \\
\hline \multicolumn{8}{|c|}{ - Before storage (diluted semen) - } \\
\hline \multirow[t]{2}{*}{10 minutes } & without & $81.0 *$ & $82.5 *$ & 1.03 & 0.23 & $<0.01$ & 0.24 \\
\hline & with & $82.0 *$ & $84.5 *$ & & & & \\
\hline \multirow[t]{2}{*}{120 minutes } & without & $72.5 \mathrm{~A}$ & $71.0 \mathrm{~A}$ & & & & \\
\hline & with & $79.0 \mathrm{~B}$ & $81.0 \mathrm{~B}$ & & & & \\
\hline \multirow{3}{*}{10 minutes } & & & urs of stor & & & & \\
\hline & without & $81.0 *$ & $82.5 *$ & 1.03 & 0.23 & $<0.01$ & 0.24 \\
\hline & with & $82.0 *$ & $84.5 *$ & & & & \\
\hline \multirow[t]{3}{*}{120 minutes } & without & $72.5 \mathrm{~A}$ & $71.0 \mathrm{~A}$ & & & & \\
\hline & with & $79.0 \mathrm{~B}$ & $81.0 \mathrm{~B}$ & & & & \\
\hline & & & urs of stor & & & & \\
\hline \multirow[t]{2}{*}{10 minutes } & without & $57.5 \mathrm{Aa}^{*}$ & $61.5 \mathrm{Ab}^{*}$ & 1.00 & 0.34 & $<0.01$ & 0.10 \\
\hline & with & $67.5 \mathrm{Ba}^{*}$ & $70.6 \mathrm{Bb}^{*}$ & & & & \\
\hline \multirow{2}{*}{120 minutes } & without & $47.5 \mathrm{~A}$ & $46.5 \mathrm{~A}$ & & & & \\
\hline & with & $64.0 \mathrm{~B}$ & $61.5 \mathrm{~B}$ & & & & \\
\hline
\end{tabular}

\footnotetext{
* Incubation period differ by $\mathrm{F}$ test $(\mathrm{P}<0.05)$

${ }^{\mathrm{ab}}$ Within each incubation time, means followed by different upper letters in the column and lower case letters in the line differ by the F-test $(\mathrm{P}<0.05)$
} 
The combination of $\mathrm{ChA}$ and caffeine was able to maintain $(\mathrm{P}<0.01)$ the percentage of mitochondria with high mitochondrial activity (PMHA) during 120min of incubation both in diluted fresh semen and in stored semen for $72 \mathrm{~h}$ (Table 2). Alone, ChA was able $(\mathrm{P}<0.05)$ to maintain this characteristic during incubation time only in the stored semen for $72 \mathrm{~h}$. ChA increased $(\mathrm{P}<0.01)$ the PMHA throughout the $120 \mathrm{~min}$ of incubation in all semen samples. Caffeine increased $(\mathrm{P}<0.01)$ the PMHA, with exception in the diluted fresh semen and semen stored for $72 \mathrm{~h}$ containing $\mathrm{ChA}$ at $10 \mathrm{~min}$ of incubation and in the semen stored for $24 \mathrm{~h}$, at 120 min of incubation.

Table 2. Percentage of mitochondria with high activity of boar semen containing or not chlorogenic acid $(\mathrm{CH})$ and caffeine (CA), evaluated in different times incubation at $37^{\circ} \mathrm{C}$ after different times of storage at $15^{\circ} \mathrm{C} . \mathrm{n}=10$

\begin{tabular}{|c|c|c|c|c|c|c|c|}
\hline \multirow{2}{*}{$\begin{array}{l}\text { Incubation } \\
\text { time }\end{array}$} & \multirow{2}{*}{$\begin{array}{l}\text { Chlorogenic } \\
\text { acid }\end{array}$} & \multicolumn{2}{|c|}{ Caffeine } & \multirow{2}{*}{ SEM } & \multicolumn{3}{|c|}{$\mathrm{P}=$} \\
\hline & & without & with & & $\mathrm{CA}$ & $\mathrm{CH}$ & $\mathrm{CH} \times \mathrm{CA}$ \\
\hline \multicolumn{8}{|c|}{ - Before storage (diluted semen) - } \\
\hline \multirow[t]{2}{*}{10 minutes } & without & $38.6 \mathrm{Aa}^{*}$ & $40.7 b^{*}$ & 0.40 & $<0.01$ & $<0.01$ & 0.09 \\
\hline & with & $40.2 \mathrm{~B} *$ & 41.2 & & & & \\
\hline \multirow[t]{3}{*}{120 minutes } & without & $36.5 \mathrm{Aa}$ & $38.5 \mathrm{Ab}$ & & & & \\
\hline & with & $38.5 \mathrm{Ba}$ & $40.8 \mathrm{Bb}$ & & & & \\
\hline & \multicolumn{7}{|c|}{-24 hours of storage - } \\
\hline \multirow[t]{2}{*}{10 minutes } & without & $38.4 \mathrm{Aa}$ & $40.9 \mathrm{Ab}^{*}$ & 0.49 & $<0.01$ & $<0.01$ & 0.88 \\
\hline & with & $41.2 \mathrm{Ba}^{*}$ & $43.2 \mathrm{Bb}^{*}$ & & & & \\
\hline \multirow[t]{2}{*}{120 minutes } & without & $37.6 \mathrm{~A}$ & $38.7 \mathrm{~A}$ & & & & \\
\hline & with & $39.6 \mathrm{~B}$ & $41.0 \mathrm{~B}$ & & & & \\
\hline \multicolumn{8}{|c|}{-72 hours of storage - } \\
\hline \multirow[t]{2}{*}{10 minutes } & without & $35.4 \mathrm{Aa}^{*}$ & $37.4 \mathrm{Ab}^{*}$ & 0.47 & $<0.01$ & $<0.01$ & 0.12 \\
\hline & with & $37.8 \mathrm{~B}$ & $39.1 \mathrm{~B}$ & & & & \\
\hline \multirow[t]{2}{*}{120 minutes } & without & $33.1 \mathrm{Aa}$ & $35.5 \mathrm{Ab}$ & & & & \\
\hline & with & $36.6 \mathrm{Ba}$ & $38.6 \mathrm{Bb}$ & & & & \\
\hline
\end{tabular}

* Incubation period differ by $\mathrm{F}$ test $(\mathrm{P}<0.05)$

${ }^{\mathrm{ab}}$ Within each incubation time, means followed by different upper letters in the column and lower case letters in the line differ by the F-test $(\mathrm{P}<0.05)$

Both ChA and caffeine did not influenced $(\mathrm{P}>0.05)$ the MDA concentration in the diluted semen (Table 3). However, caffeine increased $(\mathrm{P}<0.01)$ the MDA concentration of samples stored for $72 \mathrm{~h}$, with exception when ChA was present in the semen. ChA decreased $(\mathrm{P}<0.01)$ the MDA concentration of stored semen.

Table 3. Malondialdehyde concentration in the boar semen containing or not chlorogenic acid $(\mathrm{CH})$ and caffeine (CA), evaluated after $60 \mathrm{~min}$ of incubation at $37^{\circ} \mathrm{C}$ before and after storage at $15^{\circ} \mathrm{C} . \mathrm{n}=10$

\begin{tabular}{|c|c|c|c|c|c|c|}
\hline \multirow{2}{*}{$\begin{array}{l}\text { Chlorogenic } \\
\text { acid }\end{array}$} & \multicolumn{2}{|c|}{ Caffeine } & \multirow{2}{*}{ SEM } & \multicolumn{3}{|c|}{$\mathrm{P}=$} \\
\hline & without & with & & $\mathrm{CA}$ & $\mathrm{CH}$ & $\mathrm{CH} \times \mathrm{CA}$ \\
\hline \multicolumn{7}{|c|}{ - Before storage (diluted semen) - } \\
\hline Without & 2.27 & 2.05 & 0.10 & 0.68 & 0.88 & 0.55 \\
\hline \multicolumn{6}{|c|}{ - 72 hours of storage - } & \\
\hline Without & $5.17 \mathrm{Aa}$ & $5.93 \mathrm{Ab}$ & 0.15 & 0.01 & $<0.01$ & 0.66 \\
\hline With & 4.33B & $4.88 \mathrm{~B}$ & & & & \\
\hline
\end{tabular}

${ }^{a . b}$ Within storage time, means followed by different upper letters in the column and lower case letters in the line differ by the F-test $(\mathrm{P}<0.05)$.

The presence of $\mathrm{ChA}$ in the extender improved $(\mathrm{P}<0.01)$ the sperm viability only on the stored semen $(24$ or $72 \mathrm{~h})$, with more expressive results in the semen stored for $72 \mathrm{~h}$, evaluated at $120 \mathrm{~min}$ of incubation (Table 4). Caffeine improved the sperm viability only at $120 \mathrm{~min}$ of incubation of semen without ChA stored for $24 \mathrm{~h}$ or at $10 \mathrm{~min}$ of incubation of semen stored for $72 \mathrm{~h}$ with or without ChA. The addition of $\mathrm{ChA}$ and caffeine did not able to maintain the sperm viability throughout $120 \mathrm{~min}$ of incubation. 
ChA improved $(\mathrm{P}<0.01)$ the integrity of sperm acrosome in the diluted fresh semen only when caffeine was added (Table 5). In the semen stored for $72 \mathrm{~h}, \mathrm{ChA}$ improved the integrity of sperm acrosome in all evaluated samples. Caffeine reduced $(\mathrm{P}<0.05)$ the integrity of sperm acrosome in some samples without ChA, however, increased when ChA was present. ChA decreased $(\mathrm{P}<0.05)$ the integrity of sperm acrosome throughout $120 \mathrm{~min}$ of incubation in all semen samples. Caffeine decreased this characteristic throughout the incubation time of stored semen and the combination $\mathrm{ChA}$ and caffeine decreased only in the semen stored for $72 \mathrm{~h}$.

Table 4. Percentages of sperm viability in the boar semen containing or not chlorogenic acid $(\mathrm{CH})$ and caffeine (CA), evaluated in different times incubation at $37^{\circ} \mathrm{C}$ after different times of storage at $15^{\circ} \mathrm{C} . \mathrm{n}=$ 10

\begin{tabular}{|c|c|c|c|c|c|c|c|}
\hline \multirow{2}{*}{$\begin{array}{l}\text { Incubation } \\
\text { time }\end{array}$} & \multirow{2}{*}{$\begin{array}{c}\text { Chlorogenic } \\
\text { acid }\end{array}$} & \multicolumn{2}{|c|}{ Caffeine } & \multirow{2}{*}{ SEM } & \multicolumn{3}{|c|}{$\mathrm{P}=$} \\
\hline & & without & with & & $\mathrm{CA}$ & $\mathrm{CH}$ & $\mathrm{CH} \times \mathrm{CA}$ \\
\hline \multicolumn{8}{|c|}{ - Before storage (diluted semen) - } \\
\hline \multirow[t]{2}{*}{10 minutes } & without & 92.8 & 92.7 & 0.74 & 0.14 & 0.22 & 0.28 \\
\hline & with & 93.6 & 94.3 & & & & \\
\hline \multirow[t]{2}{*}{120 minutes } & without & 93.2 & 91.4 & & & & \\
\hline & with & 93.3 & 92.3 & & & & \\
\hline \multicolumn{8}{|c|}{-24 hours of storage - } \\
\hline \multirow[t]{2}{*}{10 minutes } & without & $89.4 \mathrm{~A}^{*}$ & $88.6 \mathrm{~A}^{*}$ & 0.70 & 0.41 & $<0.01$ & 0.01 \\
\hline & with & $93.1 \mathrm{~B}^{*}$ & $91.2 \mathrm{~B} *$ & & & & \\
\hline \multirow[t]{2}{*}{120 minutes } & without & $81.4 \mathrm{Aa}$ & $83.7 \mathrm{Ab}$ & & & & \\
\hline & with & $90.0 \mathrm{~B}$ & 89.1 B & & & & \\
\hline \multirow{3}{*}{10 minutes } & & & urs of stor & & & & \\
\hline & without & $57.5 \mathrm{Aa}^{*}$ & $61.5 \mathrm{Ab}^{*}$ & 1.00 & 0.34 & $<0.01$ & $<0.01$ \\
\hline & with & $67.0 \mathrm{Ba}^{*}$ & $70.5 \mathrm{Bb}^{*}$ & & & & \\
\hline \multirow[t]{2}{*}{120 minutes } & without & $47.5 \mathrm{~A}$ & $46.5 \mathrm{~A}$ & & & & \\
\hline & with & $64.0 \mathrm{~B}$ & $61.5 \mathrm{~B}$ & & & & \\
\hline
\end{tabular}

* Incubation period differ by $\mathrm{F}$ test $(\mathrm{P}<0.05)$

ab Within each incubation time, means followed by different upper letters in the column and lower case letters in the line differ by the F-test $(\mathrm{P}<0.05)$

Table 5. Percentages of sperm acrosome integrity of boar semen containing or not chlorogenic acid $(\mathrm{CH})$ and caffeine (CA), evaluated in different times incubation at $37^{\circ} \mathrm{C}$ after different times of storage at $15^{\circ} \mathrm{C}$. $\mathrm{n}=10$

\begin{tabular}{|c|c|c|c|c|c|c|c|}
\hline \multirow{2}{*}{$\begin{array}{l}\text { Incubation } \\
\text { time }\end{array}$} & \multirow{2}{*}{$\begin{array}{l}\text { Chlorogenic } \\
\text { acid }\end{array}$} & \multicolumn{2}{|c|}{ Caffeine } & \multirow{2}{*}{ SEM } & \multicolumn{3}{|c|}{$\mathrm{P}=$} \\
\hline & & without & with & & $\mathrm{CA}$ & $\mathrm{CH}$ & $\mathrm{CH} \times \mathrm{CA}$ \\
\hline \multicolumn{8}{|c|}{ - Before storage (diluted semen) - } \\
\hline \multirow[t]{2}{*}{10 minutes } & without & $97.1 \mathrm{a}$ & $96.0 \mathrm{Ab}$ & 0.32 & 0.79 & $<0.01$ & $<0.01$ \\
\hline & with & $97.8 *$ & $98.3 \mathrm{~B}$ & & & & \\
\hline \multirow[t]{2}{*}{120 minutes } & without & 96.3 & $95.4 \mathrm{~A}$ & & & & \\
\hline & with & $96.8 \mathrm{~b}$ & $98.0 \mathrm{Ba}$ & & & & \\
\hline \multicolumn{8}{|c|}{-24 hours of storage - } \\
\hline \multirow[t]{2}{*}{10 minutes } & without & 93.8 & $95.3 *$ & 0.62 & 0.07 & $<0.01$ & 0.04 \\
\hline & with & $95.0 *$ & 95.8 & & & & \\
\hline \multirow[t]{2}{*}{120 minutes } & without & 92.7 & $91.0 \mathrm{~A}$ & & & & \\
\hline & with & $92.5 \mathrm{a}$ & $94.3 \mathrm{Bb}$ & & & & \\
\hline \multirow{3}{*}{10 minutes } & & & urs of stor & & & & \\
\hline & without & $89.8 \mathrm{~A}^{*}$ & $90.4 \mathrm{~A}^{*}$ & 0.41 & 0.15 & $<0.01$ & 0.18 \\
\hline & with & $92.3 \mathrm{~B}^{*}$ & $91.8 \mathrm{~B} *$ & & & & \\
\hline \multirow[t]{2}{*}{120 minutes } & without & $88.5 \mathrm{Aa}$ & $85.8 \mathrm{Ab}$ & & & & \\
\hline & with & $90.2 \mathrm{~B}$ & $90.6 \mathrm{~B}$ & & & & \\
\hline
\end{tabular}


The vigour was not influenced $(\mathrm{P}>0.05)$ by the presence of both ChA and caffeine (Table 6). Despite this, there was a decrease $(\mathrm{P}<0.01)$ of movement intensity throughout the incubation period when caffeine was added to the semen. No effect of ChA and caffeine was observed in the glucose intake (Table 7).

Table 6. Vigour in scale from 0 (absence of movements) to 5 (high intensity of movements) of boar semen containing or not chlorogenic acid $(\mathrm{CH})$ and caffeine $(\mathrm{CA})$, evaluated in different times incubation at $37^{\circ} \mathrm{C}$ after different times of storage at $15^{\circ} \mathrm{C} . \mathrm{n}=10$

\begin{tabular}{|c|c|c|c|c|}
\hline \multirow{2}{*}{ Incubation time } & \multirow{2}{*}{ Chlorogenic acid } & \multicolumn{2}{|c|}{ Caffeine } & \multirow{2}{*}{$\mathrm{P}=$} \\
\hline & & without & with & \\
\hline \multicolumn{5}{|c|}{ - Before storage (diluted semen) - } \\
\hline \multirow[t]{2}{*}{10 minutes } & without & 4.0 & $4.7 *$ & $<0.01$ \\
\hline & with & 3.9 & $4.6^{*}$ & \\
\hline \multirow{2}{*}{120 minutes } & without & 3.0 & 2.8 & \\
\hline & with & 3.0 & 2.8 & \\
\hline \multirow{3}{*}{10 minutes } & -24 & of storag & & \\
\hline & without & 3.0 & $4.2 *$ & $<0.01$ \\
\hline & with & 3.0 & $4.1^{*}$ & \\
\hline \multirow[t]{2}{*}{120 minutes } & without & 2.6 & 2.0 & \\
\hline & with & 2.8 & 2.3 & \\
\hline \multirow{3}{*}{10 minutes } & -72 & of storag & & \\
\hline & without & 2.6 & $3.6^{*}$ & $<0.01$ \\
\hline & with & 2.8 & $3.5^{*}$ & \\
\hline \multirow[t]{2}{*}{120 minutes } & without & 2.0 & 1.9 & \\
\hline & with & 2.1 & 1.9 & \\
\hline
\end{tabular}

* Incubation time differ by the Friedman test $(\mathrm{P}<0.01)$

Table 7. Glucose intake in the boar semen containing or not chlorogenic acid $(\mathrm{CH})$ and caffeine $(\mathrm{CA})$, evaluated after $60 \mathrm{~min}$ of incubation at $37^{\circ} \mathrm{C}$ before and after storage at $15^{\circ} \mathrm{C} . \mathrm{n}=10$

\begin{tabular}{|c|c|c|c|}
\hline \multirow{2}{*}{ Chlorogenic acid } & \multicolumn{2}{|c|}{ Caffeine } & \multirow{2}{*}{$\mathrm{P}=$} \\
\hline & without & with & \\
\hline \multicolumn{4}{|c|}{ - Before storage (diluted semen) - } \\
\hline without & 20.2 & 15.2 & 0.14 \\
\hline with & 17.0 & 17.7 & \\
\hline \multicolumn{4}{|c|}{ - 72 hours of storage - } \\
\hline without & 14.5 & 12.0 & 0.25 \\
\hline with & 13.2 & 10.2 & \\
\hline
\end{tabular}

No significance by Frideman test $(\mathrm{P}>0.05)$.

\section{DISCUSSION}

Our results clearly indicate that the addition of ChA during storage and refrigeration can be useful to improve the semen quality of storage boar semen at $15^{\circ} \mathrm{C}$. Furthermore, our results also indicate that the presence of ChA has a beneficial effect through potentiating the positive effects of caffeine on boar semen quality with a clear mitigation of the side effects linked to caffeine addition. The results described are very important when taking into account the fact that one of the biggest current challenges for reproductive technology is the maintenance of boar semen quality stored in refrigerated conditions for prolonged periods. In addition, the 
evaluation at different incubation times is important to simulate sperm resistance after rewarming. Under practical conditions, the use of semen at different times after re-warming may contribute to the reduction of fertility rate. Thus, alternatives that can prolong sperm resistance time after re-warming are important.

Pereira et al. (2018), evaluating different doses of ChA $(0.0,1.5,3.0,4.0$ and $6.0 \mathrm{mg} / \mathrm{ml})$ concluded that the concentration of $3.2 \mathrm{mg} / \mathrm{ml}$ of this substance is the best for semen stored for 24h. However, for semen stored for a longer period, $6.0 \mathrm{mg} / \mathrm{ml}$ or more should be used. In the present study, the concentration of $4.5 \mathrm{mg} / \mathrm{mL}$ was considered an intermediary dose, giving beneficial effects for both semen stored for 24 and 72h. By other hand, Nunes (2012), evaluating different doses of caffeine $(0,2,4,6$ and $8 \mathrm{mM}$ ) added in the cooled semen concluded that the higher dose improves the vigour only in the semen stored by $48 \mathrm{~h}$, but negatively affects in lower storage times, probably due to increased metabolic activity of spermatozoa. In this case, the association between a metabolic activator and a membrane protecting substance could bring benefits to the use of the cooled sperm semen.

Reduction in sperm quality during storage is commonly correlated with oxidative damage to cell structures due to metabolism (Schulte et al., 2010), since preservation temperatures between 15 and $18^{\circ} \mathrm{C}$ do not completely stop sperm metabolism. The losses to the seminal quality are more evident after $48 \mathrm{~h}$ of cooling, reducing the reproductive performance of the herd (Pinart et al., 2013). The oxidative attack on the sperm membranes is able to modify the fluidity of the plasma membrane and interfere with enzymatic activity and in the function of ion channels (Marmunti et al., 2012), thus reducing sperm quality. On the other hand, sperm metabolism is important to guarantee the semen quality (Yeste et al., 2008). Thus, substances that accelerate sperm metabolism combined with substances with antioxidant properties could have positive effects on the quality of inseminating doses.

In the present study, we can only speculate about the mechanisms by which ChA exerts its positive effects. Other studies have reported the scavenger ability of polyphenols on sperm function (Martin-Hidalgo et al., 2011; Wittayarat et al., 2013). Thus, the scavenger activity of ChA could be an important mechanism leading to a reduction of the oxidative damage of sperm cell structures. Furthermore, the low MDA levels found in semen stored for $72 \mathrm{~h}$ in the presence of ChA indicate that the effect was able to decrease the lipid peroxidation alterations caused by ROS (Gomez-Fernandez et al., 2013; Fraser et al., 2014). Since the integrity of cell structures is crucial to maintaining sperm functionality, the reduction of the oxidative stress induced by the addition of antioxidants would improve the quality of seminal doses (Maia et al., 2009; Wittayarat et al., 2013). In the non-stored semen, the effects of ChA were not evident, probably due to the presence of natural antioxidants in the seminal plasma, which are able to protect sperm cells from oxidative damage during short periods of storage (Kowalowka et al., 2008). However, since storage is linked to a great dilution of seminal plasma factors, the addition of ChA could counteract the loss of the antioxidant effect because of the dilution of seminal plasma.

The maintenance of sperm function is also dependent on the metabolic status of the sperm since cellular activity occurs from the consumption of both extra and intracellular energy substrates. In this sense, energy production through mitochondrial pathways is of the utmost importance in eukaryotic cells. Centering on boar sperm, it is noteworthy that the total energy yielded by mitochondrial activity is a very low percentage (a maximum of 5\%) of total energy production (Marin et al., 2003). Despite this, the minimal mitochondria-based energy production is critical for the maintenance of motility and sperm capacitation in swine (Ramio-Lluch et al., 2014). Thus, sperm mitochondrial activity becomes an important evaluation parameter regardless of their intrinsic importance in the production of energy in boar sperm. With respect to the seminal metabolic rate, the addition of caffeine increased sperm mitochondrial activity only after 10min of incubation of semen stored for $72 \mathrm{~h}$. This effect of caffeine had been associated with the increase of intracellular concentrations of cAMP (Lopez e Alvarino, 2000; Carrington et al., 2011). This is important, since several sperm metabolic parameters, such as motility, are closely dependent on intracellular cAMP levels $(\mathrm{Qu}$ et al., 2007). 
On the other hand, increased intracellular concentrations of cAMP are also associated with elevated overall cell metabolic rates. In the present study, caffeine was able to increase the number of mitochondria with maximum activity even in doses that were not supplemented with $\mathrm{ChA}$. There is evidence that the phosphorylation of certain mitochondrial enzymes mediated by cAMP play a regulatory role in oxidative phosphorylation (Acin-Perez et al., 2009). Therefore, increases in cAMP could increase mitochondrial activity by stimulating oxidative phosphorylation. In contrast, while the energy generated by mitochondria is essential for sperm function, this organelle is the major source of endogenous ROS production in the cell (RamioLluch et al., 2014). It is known that ROS can impair sperm metabolism during storage or incubation. In fact, a significant increase in the MDA concentration was detected in the present study after addition of caffeine in the semen stored for $72 \mathrm{~h}$. This increase may be linked to the reduction in the PMHA and, consequently, the reduction in the vigour after 120min of incubation. The increase of MDA concentration may be associated with an increased metabolic rate, generated by caffeine's capability to increase the rate of cellular oxidative phosphorylation (Carrington et al., 2011). Despite this evidence of increased sperm metabolic rate, caffeine does not alter glucose uptake by sperm, possibly due to consumption of other energy sources, as fructose, from spermatozoa.

In the present study, the negative effects of caffeine are mitigated with the use of ChA. This fact indicates that the protective effect against sperm membrane damage can be associated with the antioxidant activity of ChA. While caffeine metabolically stimulates mitochondrial activity (Carrington et al., 2011), ChA protects the organelle from oxidative damage ( $\mathrm{Li}$ et al., 2012), promoting good conditions for its performance. (Peña et al. (2003)) also observed the beneficial effects of adding an antioxidant (vitamin E) to the mitochondrial membrane potential of thawed boar semen, showing that mitochondria are more sensitive to oxidative damage, and antioxidants have a protective effect to this structure.
In summary, the present study showed that ChA has positive effects in sperm motility (mainly after 120 minutes of incubation), percentage of mitochondria with maximum activity, MDA concentration, sperm viability (at 24 and $72 \mathrm{~h}$ of storage) and acrosome integrity (72h). Caffeine increased the sperm motility at 10 minutes of incubation of stored semen for $72 \mathrm{~h}$, percentage of mitochondria with maximal activity $(0,24$ and $72 \mathrm{~h}$ ) and sperm viability ( 24 and $72 \mathrm{~h}$ ). On other hand, caffeine increased the MDA concentration and reduced the acrosome integrity (both with $72 \mathrm{~h}$ of storage) and sperm vigour throughout the 120 minute incubation (0, 24 and $72 \mathrm{~h})$. When these substances were associated, there was an increase in the sperm motility, sperm viability, percentage of mitochondria with maximum activity (all with $72 \mathrm{~h}$ of storage) and in the acrosome integrity ( 0 and $24 \mathrm{~h}$ of storage). The reduction of sperm vigour throughout the incubation time caused by caffeine adding was not alleviated by the addition of ChA. These results suggest that the addition of $\mathrm{ChA}$ in the dilution medium is beneficial for the quality of the swine inseminating doses and that the use of caffeine before re-warming is only recommended for the semen stored for prolonged periods (72h). Although the vigour has been reduced during incubation time when these substances were used, studies in vivo and in vitro must be conducted to evaluate if this reduction could compromise the fertilization capacity of semen.

\section{CONCLUSIONS}

The addition of ChA to the dilution medium improves the quality of the swine inseminating doses. The addition of caffeine during rewarming is only recommended when the semen is stored for prolonged periods $(72 \mathrm{~h})$, and the inseminating dose should be used immediately after its addition.

\section{ACKNOWLEDGEMENTS}

The authors thank CAPES (PNPD Institucional, process number 2457/2011, and Programa Pesquisador Visitante Especial - PVE's, process number 88881.030399/2013-01), FAPEMIG (PPM-00460-12), CNPq (305478/2015-0 and 446288/2014-4), Minitub do Brasil, Fazenda São Paulo and the Postgraduate Program in Veterinary Sciences UFLA for their support. 


\section{REFERENCES}

ACIN-PEREZ, R.; SALAZAR, E.; KAMENETSKY, M. et al. Cyclic AMP produced inside mitochondria regulates oxidative phosphorylation. Cell Metab., v.9, p.265-276, 2009.

AITKEN, R.J.; GIBB, Z.; MITCHELL, L.A. et al. Sperm motility is lost in vitro as a consequence of mitochondrial free radical production and the generation of electrophilic aldehydes but can be significantly rescued by the presence of nucleophilic thiols. Biol. Reprod., v.87, p.110, 2012.

BLOM, E. A one-minute live-dead sperm stain by means of eosin-nigrosin. Fertil. Steril., v.1, p.176-177, 1950.

CARRINGTON, J.L.; CARRINGTON, A.C.; SPLAN, R.K. et al. Effect of caffeine, pentoxifylline, and taurine on post-thaw parameters of equine frozen semen. J. Equine Vet. Sci., v.31, p.325-326, 2011.

FRASER, L.; STRZEZEK, J.; KORDAN, W. Post-thaw sperm characteristics following longterm storage of boar semen in liquid nitrogen. Anim. Reprod. Sci., v.147, p.119-27, 2014.

GOMEZ-FERNANDEZ, J.; GOMEZIZQUIERDO, E.; TOMAS, C. et al. Is sperm freezability related to the post-thaw lipid peroxidation and the formation of reactive oxygen species in boars? Reprod. Domest. Anim., v.48, p.177-82, 2013.

HRUDKA, F. Cytochemical and ultracytochemical demonstration of cytochrome c oxidase in spermatozoa and dynamics of its changes accompanying ageing or induced by stress. Int. J. Andro.l, v.10, p.809-28, 1987.

JOHNSON, L.A.; WEITZE, K.F.; FISER, P. et al. Storage of boar semen. Anim. Reprod. Sci., v.62, p.143-72, 2000.

KOWALOWKA, M.; WYSOCKI, P.; FRASER, L. et al. Extracellular superoxide dismutase of boar seminal plasma. Reprod. Domest. Anim., v.43, p.490-496, 2008.

LARDY, H.A.; GARBERS, D.L.; LUST, W.D. et al. Effects of phosphodiesterase inhibitors and cyclic nucleotides on sperm respiration and motility. Biochemistry, v.10, p.1825-1831, 1971.
LI, S.; BIAN, H.; LIU, Z. et al. Chlorogenic acid protects MSCs against oxidative stress by altering FOXO family genes and activating intrinsic pathway. Eur. J. Pharmacol., v.674, p.65-72, 2012.

LOPEZ, F.J.; ALVARINO, J.M. Effects of added caffeine on results following artificial insemination with fresh and refrigerated rabbit semen. Anim. Reprod. Sci., v.58, p.147-54, 2000.

MAIA, M.D.S.; BICUDO, S.D.; AZEVEDO, H.C. et al. Motility and viability of ram sperm cryopreserved in a Tris-egg yolk extender supplemented with anti-oxidants. Small Ruminant Res., v.85, p.85-90, 2009.

MARIN, S.; CHIANG, K.; BASSILIAN, S. et al. Metabolic strategy of boar spermatozoa revealed by a metabolomic characterization. FEBS Lett., v.554, p.342-346, 2003.

MARMUNTI, M.; GUTIÉRREZ, A.M.; GAVAZZA, M. et al. Susceptibility to peroxidation and fatty acid composition of fresh boar semen obtained from different hog farms. Rev. Vet., v.23, p.8-14, 2012.

MARTIN-HIDALGO, D.; BARON, F.J.; BRAGADO, M.J. et al. The effect of melatonin on the quality of extended boar semen after longterm storage at 17 degrees C. Theriogenology, v.75, p.1550-1560, 2011.

MENDEZ, M.F.; ZANGERONIMO, M.G.; ROCHA, L.G. et al. Effect of the addition of IGF-I and vitamin $\mathrm{E}$ to stored boar semen. Animal, v.7, p.793-798, 2013.

NABAVI, N.; TODEHDEHGHAN, F.; SHIRAVI, A. Effect of caffeine on motility and vitality of sperm and in vitro fertilization of outbreed mouse in T6 and M16 media. Iran J. Reprod. Med., v.11, p.741-746, 2013.

NUMABE, T.; OIKAWA, T.; KIKUCHI, T. et al. Pentoxifylline improves in vitro fertilization and subsequent development of bovine oocytes. Theriogenology, v.56, p.225-33, 2001.

NUNES, M.B. Adição de cafeína ao sêmen suíno resfriado ou descongelado. 2012. 65f. Dissertação (Mestrado em Ciências Veterinárias). - Departamento de Medicina Veterinária, Universidade Federal de Lavras, Lavras, MG. 
PEÑA, F.J.; JOHANNISSON, A.; WALLGREN, M. et al. Antioxidant supplementation in vitro improves boar sperm motility and mitochondrial membrane potential after cryopreservation of different fractions of the ejaculate. Anim. Reprod. Sci., v.78, p.85-98, 2003.

PEREIRA, B.A.; CHAVES, B.R.; TELES, M.C. et al. Chlorogenic acid improves the quality of boar semen subjected to cooled storage at $15^{\circ} \mathrm{C}$. Andrologia, p.e12978, 2018.

PINART, E.; YESTE, M.; PUIGMULE, M. et al. Acrosin activity is a suitable indicator of boar semen preservation at 17 degrees $\mathrm{C}$ when increasing environmental temperature and radiation. Theriogenology, v.80, p.234-247, 2013.

POPE, C.E.; ZHANG, Y.Z; DRESSE, B.L. A simple staining method for evaluating acrosomal status of cat spermatozoa. Theriogenology, v.22, p.87-95, 1991.

QU, F.; YING, X.; GUO, W. et al. The role of $\mathrm{Zn}$-alpha2 glycoprotein in sperm motility is mediated by changes in cyclic AMP. Reproduction, v.134, p.569-576, 2007.

RAMIO-LLUCH, L.; YESTE, M.; FERNANDEZ-NOVELL, J.M. et al. Oligomycin A-induced inhibition of mitochondrial ATPsynthase activity suppresses boar sperm motility and in vitro capacitation achievement without modifying overall sperm energy levels. Reprod. Fertil. Dev., v.26, p.883-897, 2014.

RHEMREV, J.P.; LENS, J.W.; MCDONNELL, J. et al. The postwash total progressively motile sperm cell count is a reliable predictor of total fertilization failure during in vitro fertilization treatment. Fertil. Steril., v.76, p.884-891, 2001.

RICE-EVANS, C.A.; MILLER, N.J.; PAGANGA, G. Structure-antioxidant activity relationships of flavonoids and phenolic acids. Free Radic. Biol. Med., v.20, p.933-956, 1996.
SCHULTE, R.T.; OHL, D.A.; SIGMAN, M. et al. Sperm DNA damage in male infertility: etiologies, assays, and outcomes. J. Assist. Reprod. Genet., v.27, p.3-12, 2010.

SILVA, D.M.; ZANGERONIMO, M.G.; MURGAS, L.D.S. et al. Addition of IGF-1 to storage-cooled boar semen and its effects on sperm quality. Growth Horm. IGF Res. v.21, p.325-330, 2011.

WATERHOUSE, K.E.; DE ANGELIS, P.M.; HAUGAN, T. et al. Effects of in vitro storage time and semen-extender on membrane quality of boar sperm assessed by flow cytometry. Theriogenology, v.62, p.1638-1651, 2004.

WITTAYARAT, M.; ITO, A.; KIMURA, T. et al. Effects of green tea polyphenol on the quality of canine semen after long-term storage at 5 degrees C. Reprod. Biol., v.13, p.251-254, 2013.

XU, Y.; CHEN, J.; YU, X. et al. Protective effects of chlorogenic acid on acute hepatotoxicity induced by lipopolysaccharide in mice. Inflamm. Res., v.59, p.871-877, 2010.

YAMAGUCHI, S.; FUNAHASHI, H. Effect of the addition of beta-mercaptoethanol to a thawing solution supplemented with caffeine on the function of frozen-thawed boar sperm and on the fertility of sows after artificial insemination. Theriogenology, v.77, p.926-932, 2012

YAMAGUCHI, S.; SUZUKI, C.; NOGUCHI, M. et al. Effects of caffeine on sperm characteristics after thawing and inflammatory response in the uterus after artificial insemination with frozen-thawed boar semen. Theriogenology, v.79, p.87-93, 2013.

YESTE, M.; BRIZ, M.; PINART, E. et al. Hyaluronic acid delays boar sperm capacitation after 3 days of storage at 15 degrees C. Anim. Reprod. Sci., v.109, p.236-50, 2008. 